\title{
Microsomal formation of $S$-nitrosoglutathione from organic nitrites: possible role of membrane-bound glutathione transferase
}

\author{
Yanbin JI, Theodorus P. M. AKERBO0M and Helmut SIES* \\ Institut für Physiologische Chemie I, Heinrich-Heine Universität Düsseldorf, Postfach 101007, D-40001 Düsseldorf, Federal Republic of Germany
}

The formation of $S$-nitrosoglutathione (GSNO) from amyl nitrite and n-butyl nitrite was studied in rat liver microsomes, employing $N$-ethylmaleimide (MalNEt) as an activator and indomethacin as an inhibitor of microsomal glutathione S-transferase (GST). Rates were compared with GST activity measured with 1-chloro2,4-dinitrobenzene (CDNB) as a substrate. MalNEt stimulated GST activity and the formation of GSNO from amyl nitrite and n-butyl nitrite about 10 -fold. Increasing concentrations of indomethacin inhibited both reactions in parallel. $N$-Acetyl-L-cysteine but not L-cysteine could substitute for GSH. It is concluded that rat liver microsomal GST catalyses the formation of GSNO from amyl nitrite and n-butyl nitrite. The activity of the MalNEtstimulated microsomal GST is calculated to be about 17 units $/ \mathrm{mg}$ of enzyme with the alkyl nitrites and about 16 units/mg of enzyme with CDNB as a substrate, assuming that $3 \%$ of microsomal protein is GST. These rates are comparable with those obtained for cytosolic GSTs. Thus microsomal GST may play a significant role in the metabolism of alkyl nitrites in biological membranes.

\section{INTRODUCTION}

Nitric oxide (NO) has been shown to have numerous physiological effects, including signalling and macrophage-mediated tumor-cell-directed toxicity [1-3]. It has been suggested that NOcontaining compounds such as $S$-nitrosothiols are biologically active forms of NO [4]. In particular, $S$-nitrosoglutathione (GSNO) exhibits many NO-like activities such as inhibition of platelet activation [4,5], inhibition of neutrophil functions [6] as well as vasodilation [7], and may function as a storage pool of NO.

Amyl nitrite and n-butyl nitrite have been commonly used in relieving angina pectoris, and in some sections of the population they have been taken as stimulants [8]. These alkyl nitrites react readily with thiols to form $S$-nitrosothiols $[9,10]$. GSH is especially likely to form an $S$-nitrosothiol in vivo since it is the most abundant non-protein thiol in cells, and GSNO is more stable than $S$-nitrosocysteine (CysNO) [7,11]. Recently it was reported that GSNO formation can be catalysed by cytosolic glutathione S-transferases (GSTs) [12] and that the toxicity of n-butyl nitrite towards rat hepatocytes was mediated by this $S$-nitrosothiol [10].

The purpose of the present work was to examine a potential biofunction of microsomal GST, a unique membrane-bound enzyme that is structurally distinct from the cytosolic GSTs and is stimulated by $N$-ethylmaleimide (MalNEt) [13-15], in the above reactions.

\section{MATERIALS AND METHODS}

\section{Materials}

1-Chloro-2,4-dinitrobenzene (CDNB), amyl nitrite, n-butyl nitrite and cysteine were purchased from Merck (Darmstadt, Germany); indomethacin and bathocuproine disulphonic acid from Sigma Chemie (München, Germany); GSH from Boehringer (Mannheim, Germany); and $N$-acetyl-L-cysteine from EGA-Chemie (Steinheim, Germany). Cytosolic GSTs from rat liver obtained by affinity chromatography were kindly provided by Dr. G. Wagner from this Institute.

\section{Isolation of microsomal membranes}

Microsomes were prepared from male Wistar rats $(200-300 \mathrm{~g}$ body wt.) fed with Altromin standard diet ad libitum, as described previously [16]. Membranes were washed with $100 \mathrm{mM}$ Tris/HCl ( $\mathrm{pH}$ 7.4) and suspended in a medium containing $0.25 \mathrm{M}$ sucrose, $10 \mathrm{mM}$ Tris $/ \mathrm{HCl}\left(\mathrm{pH} \mathrm{7.4)}\right.$ and $10 \mathrm{mM} \mathrm{MgCl}_{2}$ [15].

\section{Assay of GST activity}

GST activity was measured with $1 \mathrm{mM}$ GSH and $1 \mathrm{mM}$ CDNB as substrates, as described $[17,18]$. In some experiments $1.0 \mathrm{mM}$ cysteine or $1.0 \mathrm{mM} \mathrm{N}$-acetyl-L-cysteine was used instead of $1.0 \mathrm{mM}$ GSH. Microsomes $(3.5 \mathrm{mg} / \mathrm{ml})$ or purified cytosolic GSTs $(45 \mu \mathrm{g} / \mathrm{ml})$ were treated with $1.0 \mathrm{mM}$ MalNEt for $1 \mathrm{~min}$ at room temperature. Treatment with indomethacin was performed by preincubating control or MalNEt-treated microsomes at $0-2.5 \mathrm{mM}$ for $3 \mathrm{~min}$ at room temperature, after which activity was measured by adding $10 \mu 1$ of the treated microsomes or cytosolic GSTs to $1.0 \mathrm{ml}$ of assay mixture.

\section{Assay of $S$-nitrosothiols}

$S$-Nitrosothiols were measured at $334 \mathrm{~nm}$ using the following molar absorption coefficients: $767 \mathrm{M}^{-1} \cdot \mathrm{cm}^{-1}$ for GSNO, $594 \mathrm{M}^{-1} \cdot \mathrm{cm}^{-1}$ for CysNO and $727 \mathrm{M}^{-1} \cdot \mathrm{cm}^{-1}$ for $S$-nitroso- $N$ acetyl-L-cysteine (CysNAcNO) [11]. Assays were carried out at $25^{\circ} \mathrm{C}$ in $50 \mathrm{mM} \mathrm{KCl}, 40 \mathrm{mM}$ sodium phosphate (pH 7.4), $1.5 \mathrm{mM}$ GSH, $1.0 \mathrm{mM}$ alkyl nitrites and $10 \mu \mathrm{M}$ bathocuproine disulphonate as copper chelator to stabilize the nitrosothiols $[12,19]$. In some experiments $1.5 \mathrm{mM}$ cysteine or $1.5 \mathrm{mM} \mathrm{N}$ acetyl-L-cysteine was used instead of $1.5 \mathrm{mM}$ GSH. Stock solutions $(60 \mathrm{mM})$ of amyl nitrite and n-butyl nitrite were prepared in acetone. After determination of the spontaneous rate of $S$-nitrosothiol formation, $100 \mu \mathrm{l}$ of treated microsomes $(3.5 \mathrm{mg} / \mathrm{ml})$ or cytosolic GSTs $(45 \mu \mathrm{g} / \mathrm{ml})$ was added to $1 \mathrm{ml}$ of assay mixture and the reaction rate measured. 


\section{RESULTS}

\section{Microsomal GST activity}

Microsomal GST activity with CDNB was stimulated 10 -fold by MalNEt (Figure 1a), in accordance with the results of Morgenstern et al. [13] and our previous report [15]. Indomethacin decreased microsomal GST activity both in the absence and in the presence of MalNEt. The activated enzyme activity was more susceptible to inhibition than the unactivated activity. Half-maximal inhibition of the activated enzyme was observed at $0.35 \mathrm{mM}$ indomethacin, whereas for the unactivated enzyme $0.8 \mathrm{mM}$ was required.

\section{Formation of GSNO}

Microsomes were tested for the reaction between GSH and alkyl
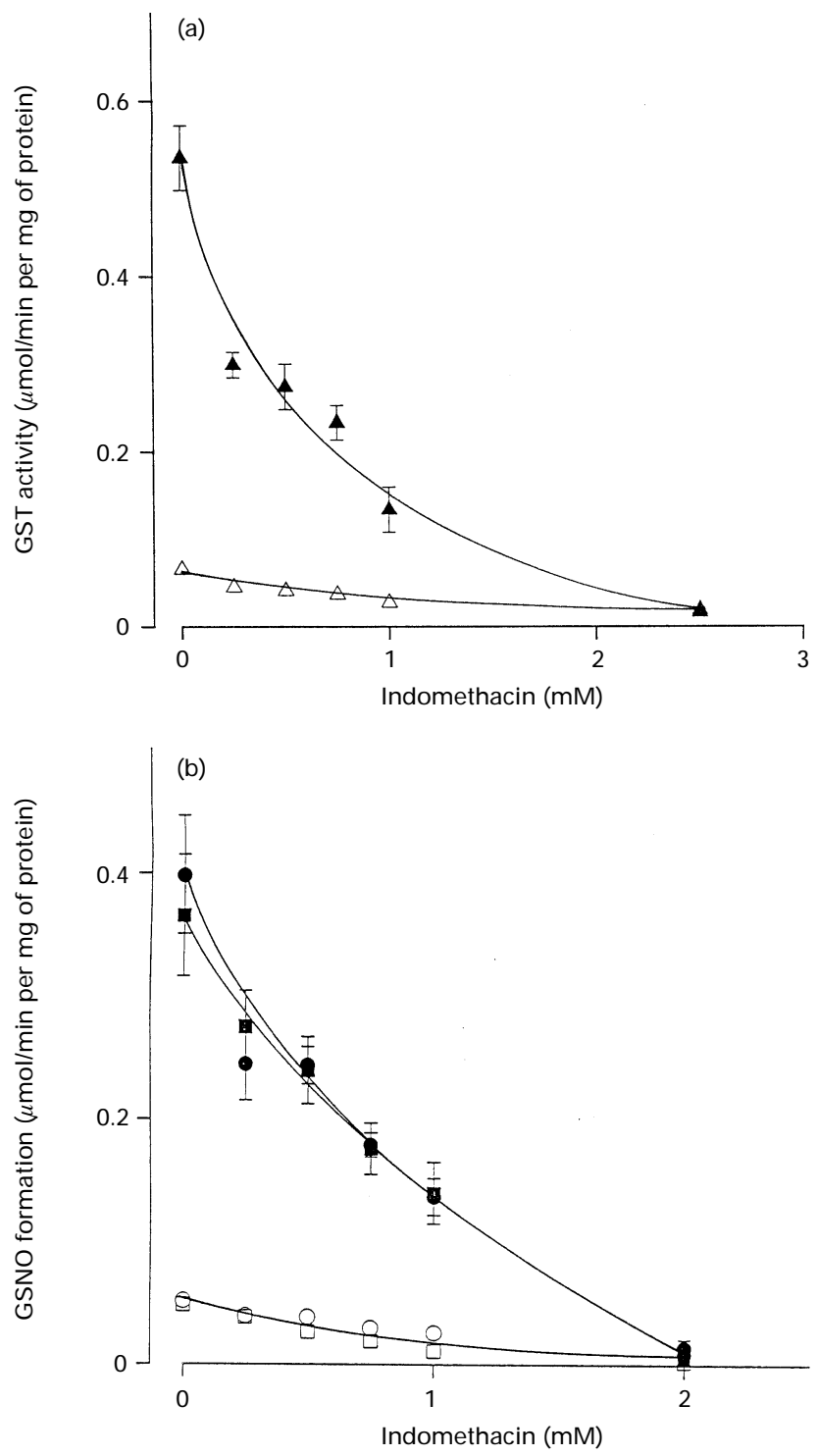

Figure 1 Inhibition of GST activity (a) and GSNO formation from amyl nitrite and n-butyl nitrite (b) by indomethacin in rat liver microsomes in the absence and presence of MalNEt

$\operatorname{CDNB}(\triangle, \boldsymbol{\Delta})$, amyl nitrite $(\bigcirc, \boldsymbol{O})$ or n-butyl nitrite $(\square$, untreated $(\triangle, \square, \bigcirc)$ and MalNEt-treated means \pm S.E.M. $(n=6)$.
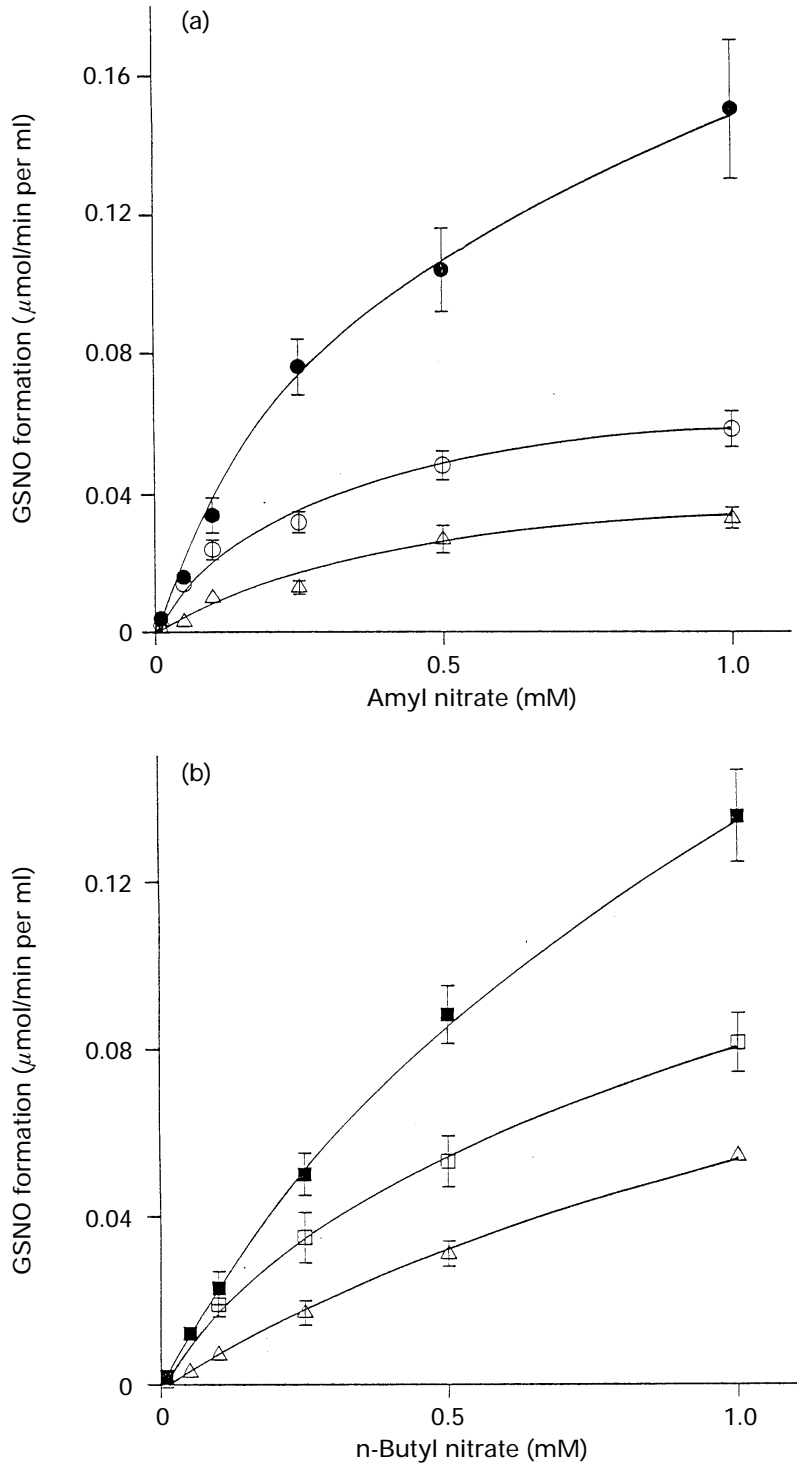

Figure 2 Formation of GSNO from amyl nitrite (a) and n-butyl nitrite (b)

The reaction of GSH with different concentrations of alkyl nitrites was measured as described in the Materials and methods section. Conditions: (a) $\triangle$, spontaneous reaction; $\bigcirc$, untreated microsomes added; MalNEt-treated microsomes added; (b) $\triangle$, spontaneous reaction; $\square$, untreated microsomes added; $\mathbf{\square}$, MalNEt-treated microsomes added. Values are means \pm S.E.M. $(n=5)$.

nitrites, and the possible involvement of GST was studied with MalNEt and indomethacin (Figure 1b). The findings described above with CDNB were also obtained for the formation of GSNO. MalNEt stimulated microsomal GSNO formation with both amyl nitrite and n-butyl nitrite, and GSNO formation was inhibited by indomethacin. Half-maximal inhibition of MalNEtstimulated GSNO formation was obtained with $0.44 \mathrm{mM}$ indomethacin; for the unstimulated reaction a value of $0.71 \mathrm{mM}$ was observed. These results suggest that the enzyme catalysing GSNO formation from alkyl nitrites in microsomal membranes is identical to microsomal GST.

\section{$K_{\mathrm{m}}$ and $V_{\max }$ of microsomal GSNO formation}

GSNO formation catalysed by microsomes followed a saturation curve at increasing concentrations of alkyl nitrites (Figure 2). On 
Table 1 Kinetic data for the formation of GSNO from GSH and alkyl nitrites in rat liver microsomes

Activities were measured at $1.5 \mathrm{mM} \mathrm{GSH}$ and $0.25-3.0 \mathrm{mM}$ alkyl nitrites. Values are means \pm S.E.M. of five experiments. Data in parentheses represent GST activity calculated as units/mg of enzyme, assuming that $3.1 \%$ of total microsomal protein is GST.

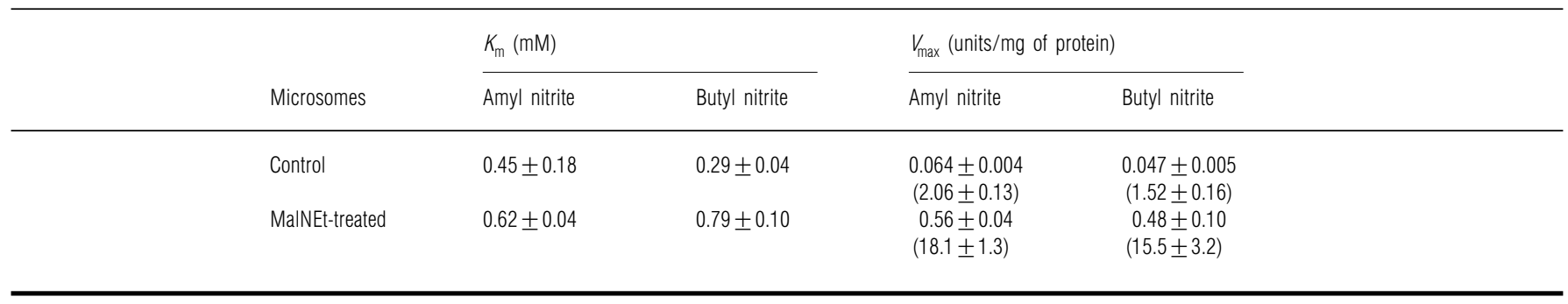

plotting the values corrected for the spontaneous reaction according to Lineweaver and Burk, a straight line was obtained. With amyl nitrite the $V_{\max }$ values for the unstimulated and stimulated enzymic reactions were 0.064 and 0.56 unit $/ \mathrm{mg}$ of protein respectively; with n-butyl nitrite values of 0.047 and $0.48 \mathrm{unit} / \mathrm{mg}$ of protein were estimated (Table 1). Thus MalNEt enhanced the $V_{\max }$ with amyl nitrite 9-fold and that with n-butyl nitrite 10 -fold. The apparent $K_{\mathrm{m}}$ values for amyl nitrite and nbutyl nitrite were $0.45 \mathrm{mM}$ and $0.29 \mathrm{mM}$ respectively in controls; MalNEt increased these values to $0.62 \mathrm{mM}$ and $0.79 \mathrm{mM}$ respectively. At saturating concentrations of alkyl nitrites accurate measurements of enzymic rates were rendered difficult due to the high spontaneous reaction rate, which for n-butyl nitrite was even faster than for amyl nitrite. Enzyme activities were therefore determined at $1 \mathrm{mM}$ alkyl nitrites.

\section{Activity with different thiols}

Three different thiols (GSH, cysteine and $N$-acetylcysteine) were tested in the formation of the corresponding $S$-nitroso- compounds, and activities in microsomes were compared with those with isolated cytosolic GSTs.

With CDNB as a substrate, MalNEt effectively stimulated microsomal GST activity, but had no obvious effect on cytosolic GSTs (Table 2). When the microsomal GST activity was expressed in $\mu \mathrm{mol} / \mathrm{min}$ per $\mathrm{mg}$ of enzyme (assuming that $3.1 \%$ of membrane protein is GST [14,20]), it was similar to that of cytosolic GSTs (16 versus $19 \mu \mathrm{mol} / \mathrm{min}$ per $\mathrm{mg}$ ). When cysteine was used instead of GSH, neither microsomal nor cytosolic GSTs showed activity with CDNB. In accordance with the results of Weinander et al. [21], substantial catalytic activity of the unactivated microsomal GST was found with $N$-acetyl-Lcysteine. The MalNEt-stimulated microsomal enzyme was much less active with $N$-acetyl-L-cysteine, and cytosolic GSTs showed no activity with this substrate.

Similar results were obtained for GSNO formation from alkyl nitrites. With GSH as the thiol substrate, microsomes as well as cytosolic GSTs catalysed $S$-nitrosothiol formation. MalNEt stimulated microsomal activity, but had no effect on cytosolic GSTs. CysNO formation from cysteine and alkyl nitrites was not detectable with either microsomes or cytosolic GSTs. Micro-

Table 2 Catalytic activities of microsomes and cytosolic GSTs with different thiols and CDNB or alkyl nitrites as substrates

Enzyme activities are expressed as means \pm S.E.M. ( $\mu \mathrm{mol} / \mathrm{min}$ per $\mathrm{mg}$ of microsomal protein) or $\mu \mathrm{mol} / \mathrm{min}$ per $\mathrm{mg}$ of cytosolic GST ( $n=6$ ). The data in parentheses are calculated as $\mu \mathrm{mol} / \mathrm{min}$ per $\mathrm{mg}$ of microsomal GST, assuming that $3.1 \%$ of microsomal protein is GST. ND, not detectable.

\begin{tabular}{|c|c|c|c|c|}
\hline \multirow[b]{3}{*}{ Substrate/thiols } & \multicolumn{4}{|c|}{ Activity $(\mu \mathrm{mol} / \mathrm{min}$ per $\mathrm{mg}$ of protein) } \\
\hline & \multicolumn{2}{|l|}{ Microsomes } & \multicolumn{2}{|c|}{ Cytosolic GSTs } \\
\hline & Control & + MalNEt & Control & + MalNEt \\
\hline \multicolumn{5}{|l|}{ CDNB } \\
\hline GSH & $\begin{array}{c}0.050 \pm 0.003 \\
(1.61 \pm 0.10)\end{array}$ & $\begin{array}{c}0.49 \pm 0.03 \\
(15.8 \pm 1.0)\end{array}$ & $19.1 \pm 3.7$ & $17.9 \pm 4.2$ \\
\hline Cys & ND - & ND & ND & ND \\
\hline CysNAc & $\begin{array}{c}0.015 \pm 0.002 \\
(0.49 \pm 0.06)\end{array}$ & $\begin{array}{l}0.003 \pm 0.001 \\
(0.11 \pm 0.02)\end{array}$ & ND & ND \\
\hline \multicolumn{5}{|l|}{ Amyl nitrite } \\
\hline GSH & $\begin{array}{l}0.052 \pm 0.007 \\
(1.68 \pm 0.23)\end{array}$ & $\begin{array}{c}0.40 \pm 0.02 \\
(12.9 \pm 0.65)\end{array}$ & $48 \pm 11$ & $44 \pm 10.5$ \\
\hline Cys & ND & ND & ND & ND \\
\hline CysNAc & $\begin{array}{c}0.015 \pm 0.002 \\
(0.49 \pm 0.06)\end{array}$ & $\begin{array}{l}0.004 \pm 0.001 \\
(0.13 \pm 0.02)\end{array}$ & ND & ND \\
\hline \multicolumn{5}{|l|}{ Butyl nitrite } \\
\hline GSH & $\begin{array}{c}0.049 \pm 0.005 \\
(1.58 \pm 0.16)\end{array}$ & $\begin{array}{c}0.34 \pm 0.02 \\
(11.0 \pm 0.64)\end{array}$ & $51 \pm 9.9$ & $48 \pm 9.6$ \\
\hline Cys & ND & ND & ND & ND \\
\hline CysNAc & $\begin{array}{l}0.012 \pm 0.001 \\
(0.38 \pm 0.03)\end{array}$ & $\begin{array}{c}0.002 \pm 0.0003 \\
(0.06 \pm 0.01)\end{array}$ & ND & ND \\
\hline
\end{tabular}


somes but not cytosolic GSTs catalysed CysNAcNO formation from $N$-acetyl-L-cysteine and amyl nitrite or n-butyl nitrite. As with CDNB, the microsomal activity with $N$-acetyl-L-cysteine was much higher in the absence of MalNEt than in its presence.

\section{DISCUSSION}

As for other members of the GST group of enzymes, rat liver microsomal GST is involved in the detoxification of numerous carcinogenic, mutagenic, toxic and pharmacologically active compounds [22]. In liver microsomes the enzyme constitutes $3.1 \%$ of total protein [14,20], and it is also located in mitochondrial outer membranes and in the plasma membrane [22,23]. It is known that cytosolic GSTs can catalyse the reaction of alkyl nitrites with GSH to produce GSNO [12]. Here we show that microsomes also catalyse this reaction, and several observations indicate the involvement of microsomal GST.

First, GSNO formation from GSH and alkyl nitrites was strongly stimulated by MalNEt (Figure 1b). Such stimulation of microsomal GST represents a rather unique property in enzymology. Since cytosolic GST is not influenced by MalNEt ([21], Table 2) or is even inhibited [24], it is excluded that contamination with cytosolic GST is responsible for microsomal GSNO formation. Second, microsomal GSNO formation is inhibited by indomethacin. The $\mathrm{IC}_{50}$ is comparable with that for microsomal GST measured with CDNB as substrate (Figure 1). Third, the microsomes catalyse the formation of $S$-nitrosothiols not only with GSH but also with $N$-acetyl-L-cysteine, whereas with cysteine only a spontaneous reaction and no microsomecatalysed reaction was seen. Similar thiol specificity was recently reported [21] for microsomal GST with CDNB as a substrate. The phenomenon that $N$-acetyl-L-cysteine can serve as a substrate for microsomal CysNAcNO formation in the absence of MalNEt but only very poorly in its presence is also observed with microsomal GST. It has been proposed that the free $\alpha$-amino group of the $\gamma$-L-Glu group in GSH, which is not present in $N$ acetyl-L-cysteine, has a key function in the effect of MalNEt [25].

We compared the microsomal with the cytosolic GST activity in rat liver (Table 2). A physiological mixture of cytosolic GST isoenzymes obtained by affinity chromatography on GSHagarose as described in [26] was used. This preparation contained mainly the Alpha subunit $2(23 \%)$, and the Mu subunits $3(27 \%)$ and $4(36 \%)$. GSNO formation expressed per mg of protein was higher in the cytosolic GST preparation than in the microsomes (Table 2). However, if microsomal GST is responsible for GSNO formation in these membranes, the specific activity is estimated to be of the same order as for the cytosolic enzymes. Recently Meyer et al. [12] investigated GSNO formation by different cytosolic GST isoenzymes from human liver. The highest values were obtained for the A1-1 and M1a-1a isoenzymes. For A2-2 the values reported were lower than the values for rat liver microsomal GST estimated here.

Unfortunately, we were unable to detect GSNO formation with purified microsomal GST. The lack of activity of the purified enzyme preparation can be explained by the presence of detergent. In our hands, the addition of $1 \%$ Triton X-100 to microsomes led to an almost complete loss of GSNO formation, leaving GST activity with CDNB intact. This was also observed with other detergents such as n-dodecyl maltoside, n-octyl glucoside, octyl thioglucoside, CHAPSO \{3-[(3-cholamidopropyl)dimethylammonio]-2-hydroxy-1-propane sulphonate\}, CHAPS and sodium deoxycholate (Y. Ji, T. P. M. Akerboom and $\mathrm{H}$. Sies, unpublished work). It might be that detergents change the enzyme's conformation or substrate binding properties and thereby decrease the enzyme activity towards the alkyl nitrites.

Our results show that $S$-nitrosothiol formation with GSH and $N$-acetyl-L-cysteine is an enzyme-catalysed process following Michaelis-Menten kinetics. The properties of the enzyme in the presence of MalNEt and indomethacin and the thiol specificity are identical to those of microsomal GST. We therefore conclude that GSNO formation proceeds via microsomal GST, which would represent a novel feature of this enzyme.

In view of the abundance of cytosolic GSTs and their high activity with alkyl nitrites, the significance of the microsomal GST is probably related to its intracellular location. Amyl nitrite and butyl nitrite are water-insoluble compounds and could be substantially membrane-bound. Recently we have shown that the hepatocyte plasma membrane is also equipped with a membrane-bound form of GST, probably identical to the microsomal enzyme [23]. Morgenstern et al. [13] calculated that, depending on the activation state of the enzyme, the membranebound GST may constitute $5-30 \%$ of total GST activity. Therefore, under physiological conditions, microsomal GST could play an important role in the metabolism of alkyl nitrites in biological membranes.

We are grateful to Dr. G. Wagner for supplying us with purified rat liver cytosolic GSTs. This work was supported by the National Foundation of Cancer Research, Bethesda, MD, U.S.A., the Robert-Pfleger Stiftung, and the Deutsche Forschungsgemeinschaft (grant Ak8/1-3).

\section{REFERENCES}

1 Moncada, S., Palmer, R. M. J. and Higgs, E. A. (1991) Pharmacol. Rev. 43, 109-142

2 Nathan, C. (1992) FASEB J. 6, 3051-3064

3 Butler, A. R. and Williams, D. L. H. (1993) Chem. Soc. Rev. 22, 233-241

4 Stamler, J. S., Jaraki, O., Osborne, J., Simon, D. I., Keaney, J., Vita, J., Singel, D., Valeri, C. R. and Loscalzo, J. (1992) Proc. Natl. Acad. Sci. U.S.A. 89, 7674-7677

5 Radomski, M. W., Rees, D. D., Dutra, A. and Moncada, S. (1992) Br. J. Pharmacol. 107, 745-749

6 Clancy, R. M. and Abramson, S. B. (1992) Anal. Biochem. 204, 365-371

7 Ignarro, L. J., Lippton, H., Edwards, J. C., Baricos, W. H., Hyman, A. L., Kadowitz, P. J. and Gruetter, C. A. (1981) J. Pharmacol. Exp. Ther. 218, 739-749

8 Sigell, L. T., Kapp, F. T., Fusaro, G. A., Nelson, E. D. and Falck, R. S. (1978) Am. J. Psychiatry 135, 1216-1218

9 Patel, H. M. S. and Williams, D. L. H. (1990) Chem. Soc. Perkins Trans. 2 37-42

10 Meloche, B. A. and O‘Brien, P. J. (1993) Xenobiotica 23, 863-871

11 Mathews, W. R. and Kerr, S. W. (1993) J. Pharmacol. Exp. Ther. 267, 1529-1537

12 Meyer, D. J., Kramer, H. and Ketterer, B. (1994) FEBS Lett. 351, 427-428

13 Morgenstern, R., DePierre, J. W. and Ernster, L. (1979) Biochem. Biophys. Res. Commun. 87, 657-663

14 Morgenstern, R., Guthenberg, C. and DePierre, J. W. (1982) Eur. J. Biochem. 128, 243-248

15 Horbach, M. E., Sies, H. and Akerboom, T. P. M. (1993) Biochim. Biophys. Acta 1148, 61-66

16 Cadenas, E. and Sies, H. (1982) Eur. J. Biochem. 124, 349-356

17 Habig, W. H., Pabst, M. J. and Jacoby, W. B. (1974) J. Biol. Chem. 249, 7130-7139

18 Keen, J. H., Habig, W. H. and Jacoby, W. B. (1976) J. Biol. Chem. 251, 6183-6188

19 Meyer, D. J., Kramer, H., Özer, N., Coles, B. and Ketterer, B. (1994) FEBS Lett. 345 , 177-180

20 Morgenstern, R., Lundqvist, G., Andersson, G., Balk, L. and DePierre, J. W. (1984) Biochem. Pharmacol. 33, 3609-3614

21 Weinander, R., Andersson, C. and Morgenstern, R. (1994) J. Biol. Chem. 269, 71-76

22 Andersson, C., Mosialou, E., Weinander, R. and Morgenstern, R. (1994) Adv. Pharmacol. 27, 19-35

23 Horbach, M. E., Sies, H. and Akerboom, T. P. M. (1994) Eur. J. Biochem. 222 91-96

24 Askelöf, P., Guthenberg, C., Jakobson, I. and Mannervik, B. (1975) Biochem. J. 147, 513-522

25 Andersson, C., Mosialou, E., Adang, A. E. P., Mulder, G. J., van der Gen, A. and Morgenstern, R. (1991) J. Biol. Chem. 266, 2076-2079

26 Meyer, D. J., Lalor, E., Coles, B., Kispert, A., Alin, P., Mannervik, B. and Ketterer, B. (1989) Biochem. J. 260, 785-788 